\title{
SISTEM REKOMENDASI PERTANIAN PADA ARSITEKTUR AGRIBUSINESS E-MARKETPLACE
}

\author{
Erna Piantari1*; Herdi Ashaury33; Enjun Junaeti ${ }^{2}$ \\ Departemen Pendidikan Ilmu Komputer ${ }^{1,2}$ \\ Universitas Pendidikan Indonesia \\ www.upi.edu \\ erna.piantari@upi.edu1; enjun@upi.edu² \\ Teknik Informatika ${ }^{3}$ \\ Universitas Jenderal Achmad Yani \\ herdi.ashaury@lecture.unjani.ac.id ${ }^{3}$ \\ *Contributor Author
}

\begin{abstract}
Currently the development of information technology has driven the development of e-commerce which is quite promising in Indonesia. This development has brought an era of new digital-based creative developments. Agriculture as one of the economic and community welfare bases in Indonesia needs to be developed and supported with digital finance. Several agricultural markets have been established in Indonesia to help farmers to participate in digital economic activities. Some e-commerce systems that have been built in Indonesia only help the downstream process or the marketing process. While farmers need information that can help them for agricultural purposes. Machine learning technology uses data collected in the agricultural marketplace system to be used in building a social assessment system. Recommendations for agricultural activities are adjusted to the cost of agriculture, location of agriculture, pricing of agricultural commodities at the time of receipt and timing of agricultural activities. In this research an analysis and design of an agricultural e-commerce system will be provided to provide farmers to sell their agricultural products at competitive prices and help farmers to obtain information that can be used to plan further agricultural activities.
\end{abstract}

Keywords: E-Commerce, Requirement Analyst, Agriculture, Recommendation System

Intisari-Saat ini perkembangan teknologi informasi telah mendorong perkembangan ecommerce yang cukup menjanjikan di Indonesia. Perkembangan tersebut telah membawa era perekonomian kreatif baru yang berbasis digital. Pertanian sebagai salah satu basis perekonomian dan kesejahteraan masyarakat di Indonesia perlu ikut berkembang dan sejalan dengan perekonomian digital. Beberapa marketplace pertanian telah dibangun di Indonesia untuk membantu petani untuk ikut serta dalam kegiatan ekonomi digital. Beberapa sistem e-commerce yang sudah dibangun di Indonesia hanya membantu proses hilir atau proses pemasaran saja. Sedangkan petani membutuhkan informasi yang dapat membantu mereka untuk merencanakan kegiatan pertanian. Teknologi machine learning memungkinkan untuk menggunakan data yang dihimpun dalam sistem marketplace pertanian untuk digunakan dalam membangun suatu sistem rekomendasi kegiatan pertanian yang dapat menguntungkan petani. Rekomendasi kegiatan pertanian ini disesuaikan dengan biaya pertanian, lokasi pertanian, harga prediksi komoditas pertanian saat panen dan waktu kegiatan pertanian. Dalam penelitian ini akan dilakukan analisis dan perancangan sistem e-commerce pertanian yang memungkinkan petani untuk menjual produk pertaniannya sesuai dengan harga yang bersaing serta membantu petani untuk memperoleh informasi yang dapat digunakan untuk melakukan perencanaan kegiatan pertanian selanjutnya.

Kata Kunci: E-Commerce, Analisis Kebutuhan, Pertanian, Sistem Rekomendasi

\section{PENDAHULUAN}

Perkembangan teknologi informasi telah mendorong perkembangan e-commerce yang cukup baik di Indonesia. Perkembangan tersebut telah membawa era perekonomian kreatif baru yang berbasis digital. Pertanian sebagai salah satu basis perekonomian dan kesejahteraan masyarakat di Indonesia perlu ikut berkembang dan sejalan dengan perekonomian digital. Beberapa marketplace pertanian telah dibangun di Indonesia 
untuk membantu petani untuk ikut serta dalam kegiatan ekonomi digital.

Keberadaan marketplace tersebut cukup dirasakan manfaatnya oleh petani maupun oleh konsumen. Hal karena karena marketplace yang telah dibangun telah berhasil memutus rantai distribusi produk pertanian sehingga dapat meningkatkan keuntungan petani dan menurunkan biaya yang harus dibayar konsumen (Wang \& Tong, 2010). Beberapa sistem $e$ commerce yang sudah dibangun di Indonesia hanya membantu proses hilir atau proses pemasaran saja. Namun selain proses pemasaran dan distribusi produk, petani juga memerlukan suatu sistem yang dapat membantu petani merencanakan kegiatan pertaniannya (Savla et al., 2015).

Petani membutuhkan informasi yang dapat membantu mereka untuk merencanakan kegiatan pertanian. Perencanaan yang tidak baik dapat mengakibatkan kerugian bagi petani. Kerugian ini tidak hanya karena gagal panen, namun juga kerugian karena hal lainnya. Sebagai contoh pada bulan Januari 2019 para petani buah naga di Kabupaten Banyuwangi mengalami banyak kerugian. Kerugian ini justru terjadi karena melimpahnya hasil panen petani buah naga sedangkan permintaan komoditas tersebut tidak meningkat. Hal ini mengakibatkan harga komoditas buah naga tersebut menurun drastis (Fanani Ardian, 2019). Pemerintah telah melakukan berbagai upaya untuk membantu petani melakukan perencanaan kegiatan pertanian sehingga dapat menghindari berbagai kondisi kerugian. Salah satu upaya yang dilakukan pemerintah adalah dengan melakukan pendampingan penyuluhan pertanian . Teknologi machine

learning memungkinkan untuk menggunakan data yang dihimpun dalam sistem marketplace pertanian untuk digunakan dalam membangun suatu sistem rekomendasi kegiatan pertanian yang dapat menguntungkan petani. Rekomendasi kegiatan pertanian ini disesuaikan dengan biaya pertanian, lokasi pertanian, harga prediksi komoditas pertanian saat panen dan waktu kegiatan pertanian (Zong \& Zhu, 2012). Beberapa penelitian sebelumnya telah dilakukan untuk mengintegrasikan sistem e-commerce dengan integrasi teknologi data mining, sistem prediksi maupun sistem rekomendasi (Yu et al., 2009)(Rastegari \& Md. Sap, 2008)(Savla et al., 2015).

Dalam penelitian ini akan dilakukan analisis dan perancangan sistem e-commerce pertanian yang memungkinkan petani untuk menjual produk pertaniannya sesuai dengan harga yang bersaing serta membantu petani untuk memperoleh informasi yang dapat digunakan untuk melakukan perencanaan kegiatan pertanian selanjutnya .

\section{BAHAN DAN METODE}

Pada bab ini akan dibahas mengenai metodelogi penelitian yang akan dilakukan dalam penelitian ini. Secara umum metodologi penelitian tersebut dapat dilihat pada Gambar 1.

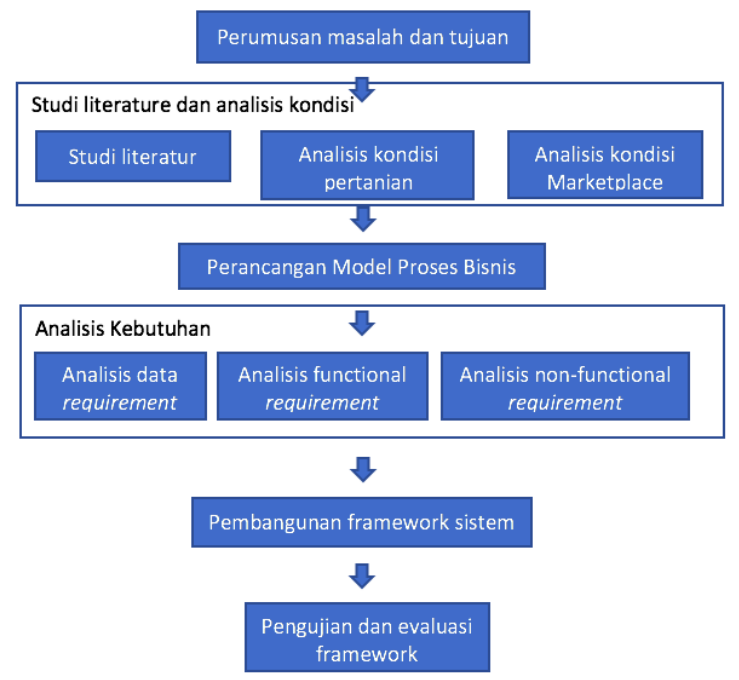

Sumber: (Piantari, Ashaury, \& Junaeti, 2019)

Gambar 1. Metodelogi Penelitian

\section{Perumusan Masalah dan Tujuan}

Pada tahap ini dilakukan perumusan masalah yang akan menjadi fokus dalam penelitian beserta tujuan dari penelitian. Tahap ini sudah dilakukan dan sudah disampaikan hasil perumusan masalah dan tujuan penelitian dalam proposal penelitian ini.

\section{Studi Literatur dan Analisis Kondisi}

Proses studi literatur dan analisis kondisi dilakukan untuk mengetahui keadaan "as is" pada saat penelitian ini dilakukan. Studi literatur dilakukan dengan mempelajari beberapa kajian teori maupun penelitian-penelitian terkait yang pernah dilakukan. Sedangkan analisis kondisi yang dilakukan adalah dengan melihat kondisi marketplace dan kondisi pertanian yang menjadi objek kajian dalam penelitian ini.

\section{Perancangan Model Proses Bisnis}

Setelah dilakukan proses studi literatur dan analisis kondisi, tahapan selanjutnya adalah merancang model proses bisnis yang akan digunakan untuk membangun sistem berdasarkan tujuan penelitian. Proses merancang model bisnis dilakukan dengan mempertimbangkan hasil dari studi literatur dan analisis kondisi. 


\section{Analisis Kebutuhan}

Kebutuhan sistem akan muncul setelah perancangan model bisnis sistem dibangun. Secara umum kebutuhan sistem terbagi menjadi tiga yaitu:

a. Kebutuhan data, kebutuhan ini berhubungan dengan tujuan penelitian untuk membangun sistem e-commerce yang mampu memberikan rekomendasi kepada petani dalam menjalankan kegiatan pertaniannya. Proses rekomendasi yang dilakukan adalah berdasarkan data riil yang dikumpulkan oleh sistem.

b. Kebutuhan functional, kebutuhan ini berhubungan dengan fungsi/fitur yang harus ada dalam sistem untuk dapat menjalankan proses bisnis yang telah dibangun.

c. Kebutuhan non-functional lainnya, yaitu kebutuhan sistem yang tidak berhubungan dengan fungsi/fitur sistem seperti kebutuhan security, ketersediaan sistem, dan sebagainya.

Pada tahapan analisis kebutuhan ini, akan didefinisikan kebutuhan-kebutuhan sistem untuk menjalankan model proses bisnis yang telah dibangun.

\section{Pembangunan Aplikasi}

Tahapan pembangunan aplikasi dari sistem e-commerce adalah tahapan implementasi dari hasil perancangan model proses bisnis dan hasil analisis kebutuhan. Proses pembangunan aplikasi akan dilakukan dengan mempertimbangkan teknologi terbaru berdasarkan hasil studi literatur.

\section{Pengujian dan Evaluasi Framework}

Pengujian dan evaluasi rancang bangun aplikasi perlu dilakukan untuk mengetahui bagaimana rancangan framework yang dibangun.

\section{HASIL DAN PEMBAHASAN}

E-commerce merupakan suatu mekanisme transaksi yang terjadi secara online dan $e$ marketplace merupakan suatu tempat berkumpulnya beberapa pelaku transaksi yang keberadaan tempatnya tersebut dibuat secara virtual melalui media elektronik. Dalam penelitian dilakukan analisis beberapa e-commerce maupun marketplace serta proses bisnis yang terjadi di dalamnya. Hasil analisis perbandingan e-commerce di Indonesia disajikan pada Tabel 1.

Dalam penelitian ini juga dilakukan analisis $e$ commerce yang khusus dibangun untuk agricultur. Salah satu agriculture e-commerce yang paling terkenal di Indonesia adalah TaniHub. TaniHub merupakan e-commerce yang menghubungkan petani dengan kapasitas kecil dengan sekelompok pelaku bisnis yang membutuhkan produk pertanian, termasuk hotel, restoran dan penjual retail. Sebelumnya TaniHub menjual produknya di platform e-commerce lainnya seperti Tokopedia, namun sejalan dengan perkembangan bisnisnya, saat ini TaniHub membuat platform sendiri yang memfasilitasi pembeli untuk melakukan transaksi di aplikasinya. Namun dilihat dari market share untuk TaniHub masih belum maksimal. Oleh sebab itu, model bisnis perancangan e-commerce taniHub perlu dievaluasi.

\section{Framework Agribisnis E-Marketplace}

Berdasarkan hasil analisis SCM agricultur dan analisis perkembangan e-commerce di Indonesia telah dibangun sebuah framework, untuk e-marketplace agribisnis yang mengimplementasi-kan model bisnis C2C, B2C, B2B dan C2B (Piantari et al., 2019). Selanjutkan dalam penelitian ini dirancang pula framework emarketplace agribisnis dengan menambahkankan proses data mining dalam arsitekturnya. Gambar 2 di bawah ini adalah framework e-marketplace agribisnis.

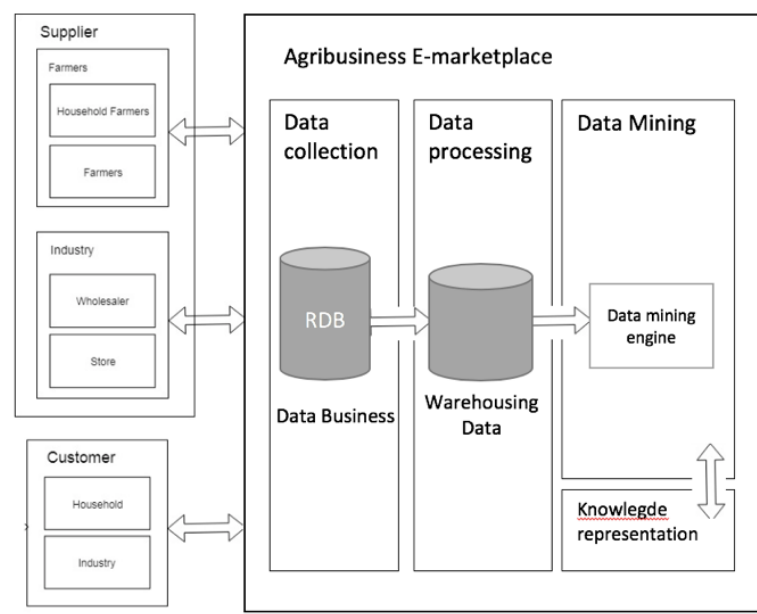

Sumber: (Piantari, Ashaury, \& Junaeti, 2019)

Gambar 2. Framewrok E-marketplace Pertanian dengan mengimplementasikan Data Mining

Model bisnis yang dibangun untuk aristektur e-marketplace yang dirancang memungkinkan untuk menjalankan model bisnis C2C, B2C, B2B, C2B. Perancangan tersebut didasari bahwa dari hasil analisis yang dilakukan, model bisnis yang berkembang untuk e-commerce di Indonesia adalah model bisnis e-marketplace dengan mengkolaborasikan berbagai model bisnis (Piantari et al., 2019). Sedangkan untuk model bisnis taniHub yang hanya menerapkan B2C dan B2B masih kurang memperoleh marketshare yang maksimal. Hal lain yang perlu diperhatikan dalam 
merancang framework e-marketplace untuk agribisnis adalah:

1. Dengan mengkolaborasikan beberapa model bisnis maka perlu diperhatikan karakteristik pelaku bisnis pertanian. Terdapat beberapa skala pelaku usaha agribisnis. Sesuai dengan latar belakang penelitian, pelaku bisnis yang akan menjadi prioritas utama adalah petani. Sehingga framework e-marketplace yang dibangun akan memberikan peluang yang sebesar-besarnya bagi petani untuk memperbaiki proses bisnis pertaniannya.

2. Komoditas pertanian memiliki usia ketahanan yang sangat singkat. Oleh karena itu, komoditas pertanian adalah komoditas yang membutuhkan perhatian yang lebih pada proses distribusi. Dari framework yang dibangun terdapat 8 jenis distribusi yang mungkin.

a. Petani skala kecil ke konsumen akhir

b. Petani skala besar ke konsumen akhir

c. Petani skala kecil ke industri

d. Petani skala besar ke industri

e. Retailer ke konsumen akhir

f. Retailer ke industri

g. Pedagang tradisional ke konsumen akhir

h. Pedagang tradisional ke industri

Proses rekomendasi aktivitas pertanian dilakukan dengan menggunakan perspektif penggunaan data mining engine untuk menghasilkan knowledge based yang dijadikan pengetahuan untuk proses rekomendasi. Proses umum data mining terdiri dari data collection, data processing, data mining, dan knowledge representation.

Data collection atau pengumpulan data adalah seluruh proses bisnis yang ada pada kegiatan dalam e-marketplace yang menghasilkan data. Data yang paling banyak dikumpulkan adalah data transaksional yang disimpan dalam database transaksional atau RDB data business. Data yang telah dikumpulkan, kemudian di proses secara historical dalam data warehousing. Proses ini merupakan bagian dari data processing sebelum proses data mining dilakukan. Proses data mining dilakukan dengan menggunakan algoritma machine learning tertentu yang selanjutkan akan menghasilkan pola yang disimpan di pattern reporsitory dan direpresentasikan sebagai knowledge yang digunakan untuk merekomendasikan aktifitas pertanian.

\section{Perancangan Aplikasi}

Berdasarkan hasil analisis yang dilakukan, terdapat 12 kebutuhan fungsional terhadap sistem rekomendasi dan pertanian yang akan dibuat.
Kebutuhan-kebutuhan fungsional tersebut, dijelaskan dalam tabel 1.

Tabel 1 Kebutuhan Functional

\begin{tabular}{|c|c|c|}
\hline $\begin{array}{l}\text { Kode } \\
\text { FR }\end{array}$ & Nama & $\begin{array}{l}\text { han Functional } \\
\text { Keterangan }\end{array}$ \\
\hline FR01 & $\begin{array}{l}\text { Memilih } \\
\text { lokasi }\end{array}$ & $\begin{array}{l}\text { Memasukan } \\
\text { informasi lokasi user }\end{array}$ \\
\hline FR02 & $\begin{array}{l}\text { Melihat } \\
\text { ketersediaan } \\
\text { komoditas } \\
\text { berdasarkan } \\
\text { wilayah }\end{array}$ & $\begin{array}{l}\text { Mencari komoditas } \\
\text { tertentu berdasarkan } \\
\text { wilayah yang sudah } \\
\text { ditentukan }\end{array}$ \\
\hline FR03 & $\begin{array}{l}\text { Melihat dan } \\
\text { memilih } \\
\text { komoditas } \\
\text { tertentu }\end{array}$ & $\begin{array}{l}\text { Melihat komoditas } \\
\text { tertentu tanpa } \\
\text { dibatasi wilayah }\end{array}$ \\
\hline FR04 & Chatbox & $\begin{array}{l}\text { Ruang untuk } \\
\text { melakukan } \\
\text { komunikasi live } \\
\text { dengan user lain }\end{array}$ \\
\hline FR05 & $\begin{array}{l}\text { Transaksi } \\
\text { Pembayaran }\end{array}$ & $\begin{array}{l}\text { Melakukan } \\
\text { pembayaran } \\
\text { transaksi yang } \\
\text { dilakukan }\end{array}$ \\
\hline FR06 & $\begin{array}{l}\text { Memasang } \\
\text { iklan } \\
\text { kebutuhan } \\
\text { komoditas }\end{array}$ & $\begin{array}{l}\text { Memasang iklan } \\
\text { terhadap kebutuhan } \\
\text { komoditas yang dicari }\end{array}$ \\
\hline FR07 & $\begin{array}{l}\text { Membuat } \\
\text { account }\end{array}$ & $\begin{array}{l}\text { Sign up sebagai user } \\
\text { tertentu }\end{array}$ \\
\hline FR08 & $\begin{array}{l}\text { Perencanaan } \\
\text { pertanian }\end{array}$ & $\begin{array}{l}\text { Melakukan } \\
\text { perencanaan } \\
\text { komoditas pertanian, } \\
\text { lahan pertanian, } \\
\text { kebutuhan pertanian }\end{array}$ \\
\hline FR09 & $\begin{array}{l}\text { Memasang } \\
\text { iklan } \\
\text { komoditas }\end{array}$ & $\begin{array}{l}\text { Memposting iklan } \\
\text { komoditas yang akan } \\
\text { dijual }\end{array}$ \\
\hline FR10 & $\begin{array}{l}\text { Memasang } \\
\text { iklan } \\
\text { prediksi } \\
\text { panen }\end{array}$ & $\begin{array}{l}\text { Memposting iklan } \\
\text { komoditas tertentu } \\
\text { yang diprediksi akan } \\
\text { panen, dengan lokasi } \\
\text { tertentu, lahan dan } \\
\text { usia tanaman }\end{array}$ \\
\hline FR11 & $\begin{array}{l}\text { Konfirmasi } \\
\text { notifikasi } \\
\text { transaksi }\end{array}$ & $\begin{array}{l}\text { Melakukan } \\
\text { konfirmasi transaksi } \\
\text { penjualan }\end{array}$ \\
\hline FR12 & $\begin{array}{l}\text { Menarik } \\
\text { hasil } \\
\text { pembayaran }\end{array}$ & $\begin{array}{l}\text { Menarik nominal } \\
\text { uang yang masuk } \\
\text { kedalam account }\end{array}$ \\
\hline
\end{tabular}

Berdasarkan kebutuhan fungsional tersebut, dipetakan menjadi tujuh aktivitas utama dalam sistem. Aktivitas yang bisa dilakukan oleh sistem, digambarkan menggunakan Usecase diagram. 
Gambar 2 adalah gambaran usecase sistem emarketplace agribusiness yang dirancang berdasarkan hasil analisis dari framework yang telah dibangun. Usecase diagram digunakan sebagai acuan dalam pengembangan Aplikasi yang akan dibuat. Penjelasan untuk setiap usecase dijelaskan pada Tabel 2 .

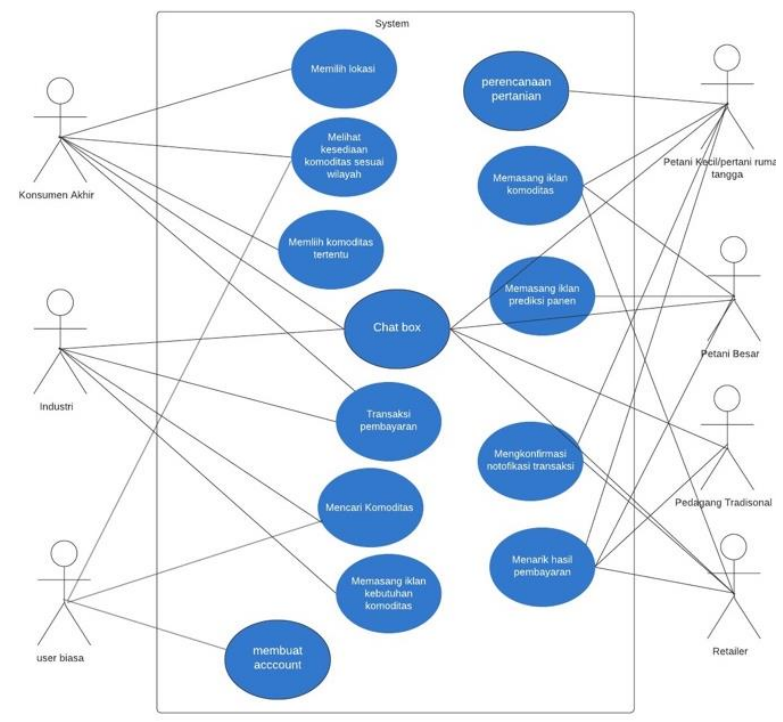

Sumber: (Piantari, Ashaury, \& Junaeti, 2019) Gambar 2. Use Case Diagram

Tabel 2. Deskripsi Usecase

\begin{tabular}{lll}
\hline $\begin{array}{l}\text { Kode } \\
\text { Usecase }\end{array}$ & $\begin{array}{l}\text { Nama } \\
\text { Usecase }\end{array}$ & Keterangan \\
\hline UC1 & $\begin{array}{l}\text { Konsumen } \\
\text { akhir }\end{array}$ & $\begin{array}{l}\text { Pihak yang membeli } \\
\text { barang untuk } \\
\text { dikonsumsi }\end{array}$ \\
\hline UC2 & Industri & $\begin{array}{l}\text { Pihak yang membeli } \\
\text { barang untuk } \\
\text { kebutuhan industry } \\
\text { dengan skala besar }\end{array}$ \\
\hline UC3 & User biasa & $\begin{array}{l}\text { User yang tidak } \\
\text { memiliki account }\end{array}$ \\
\hline UC4 & $\begin{array}{l}\text { Petani rumah } \\
\text { tangga }\end{array}$ & $\begin{array}{l}\text { Petani dengan skala } \\
\text { produksi rumah tangga }\end{array}$ \\
\hline UC5 & Petani besar & $\begin{array}{l}\text { Petani dengan skala } \\
\text { besar }\end{array}$ \\
\hline UC6 & $\begin{array}{l}\text { Pedagang } \\
\text { tradisional }\end{array}$ & $\begin{array}{l}\text { Pedagang } \\
\text { eceran/warung }\end{array}$ \\
\hline UC7 & Retailer & $\begin{array}{l}\text { Pedagang besar dengan } \\
\text { jumlah komoditas lebih } \\
\text { banyak dan beragam }\end{array}$ \\
\hline Sumber: (Piantari, Ashaury, \& Junaeti, 2019)
\end{tabular}

Untuk menunjukan pemetaan dari hasil perancangan menggunakan usecase dengan kebutuhan fungsional sistem, dijelaskan pada tabel 3.

Tabel 3 Mapping user pada setiap kebutuhan functionalnya

\begin{tabular}{ll}
\hline Kode Usecase & Kode \\
\hline UC1 & FR01, FR02, FR03, FR05, FR04 \\
\hline UC2 & FR03, FR04, FR05 \\
\hline UC3 & FR02, FR07 \\
\hline UC4 & FR04, FR08, FR09, FR11, FR12 \\
\hline UC5 & FR04, FR08, FR09, FR10, FR11, \\
& FR12 \\
\hline UC6 & FR04, FR09, FR11, FR12 \\
\hline UC7 & FR04, FR09, FR11, FR12 \\
\hline
\end{tabular}

Sumber: (Piantari, Ashaury, \& Junaeti, 2019)

Selanjutnya fungsi-fungsi sistem tersebut akan mendukung arsitektur e-marketpalce yang digunakan untuk pembangunan sistem rekomendasi pertanian pada sistem marketplace agribusiness, sehingga fungsi dari sistem dapat mencapai tujuan yang optimal secara bisnis proses yang dijalankan dan secara fungsi sebagai sistem rekomendasi pertanian.

\section{KESIMPULAN}

Berdasarkan analisis tren ekonomi dan pasar, saat ini perekonomian di Indonesia didominasi oleh aktivitas transaksi yang berjalan online melalui berbagai platform, dan platform transaksi yang paling cepat berkembang adalah emarketplace. Sejalan dengan tren ini, maka dalam tulisan ini, kami merancang arsitektur emarketplace untuk agribisnis. Model bisnis yang diterapkan dalam arsitektur yang dibangun adalah kombinasi dari B2B, B2C, C2B dan C2C. Dengan menganalisis karakteristik argiculture Supply Chain Mmanagement, hal terpenting yang harus dipertimbangkan dalam membangun arsitektur ini adalah proses penyaluran. Proses distribusi yang disediakan dalam e-marketpalce ini berbeda tergantung pada proses bisnis yang dilakukan. Dari hasil analisis diperoleh 4 layanan distribusi yang harus tersedia di e-marketplace pertanian. Selanjutkan sistem rekomendasi dibangun dengan mengerapkan proses data mining dari data transaksional yang dihasilkan dari proses bisnis emarketpalce tersebut. Hasil dari proses data mining akan direpresentasikan sebagai knowledge based untuk sistem rekomendasi aktifitas pertanian yang dapat digunakan oleh user khususnya petani.

Dari perancangan yang telah dilakukn secara umum terdapat 7 usecase utama dengan 12 fungsi sistem utama yang dapat mendukung pembangunan sistem rekomendasi pertanian yang diterapkan pada sistem e-marketplace agribusiness. Dengan menerapakan ke-7 usecase tersebut dan 12 fungsinya, maka sistem yang dibangun dapat optimal secara proses bisnis maupun secara fungsinya sebagai sistem rekomendasi. 


\section{REFERENSI}

Fanani Ardian. (2019). Harga Buah Naga di Banyuwangi Anjok, Ini Penyebabnya. Detik.Com. https://finance.detik.com/beritaekonomi-bisnis/d-4394385/harga-buahnaga-di-banyuwangi-anjlok-ini-penyebabnya

Piantari, E., Ashaury, H., Enjun, \& Nagalla, V. H. (2019). An Architecture of Market-Place Platform for Agribusiness In Indonesia. 2019 7th Mathematics, Science, and Computer Science Education International Seminar (MSCEIS).

Rastegari, H., \& Md. Sap, M. (2008). Data mining and e-commerce : methods, applications, and challenges. Jurnal Teknologi Maklumat, 20(2), 116-128.

Savla, A., Israni, N., Dhawan, P., Mandholia, A., Bhadada, H., \& Bhardwaj, S. (2015). Survey of classification algorithms for formulating yield prediction accuracy in precision agriculture. ICIIECS 2015 - 2015 IEEE International Conference on Innovations in Information, Embedded and Communication Systems, 1-7. https://doi.org/10.1109/ICIIECS.2015.71931 20

Wang, C., \& Tong, H. (2010). Research on psychological dimensions of e-commerce customer satisfaction. Proceedings of the International Conference on E-Business and EGovernment, ICEE 2010, 2105-2108. https://doi.org/10.1109/ICEE.2010.532

Yu, H., Huang, X., Hu, X., \& Wan, C. (2009). Knowledge management in e-commerce: A data mining perspective. 2009 International Conference on Management of E-Commerce and e-Government, ICMeCG 2009, 152-155. https://doi.org/10.1109/ICMeCG.2009.109

Zong, J., \& Zhu, Q. (2012). Apply grey prediction in the agriculture production price. Proceedings - 2012 4th International Conference on Multimedia and Security, MINES 2012, 396399.

https://doi.org/10.1109/MINES.2012.78 